\title{
TINGKAT CULTURE SHOCK DI LINGKUNGAN MAHASISWA UNSIKA
}

\author{
Cut Nuraini ${ }^{*}$, Dadang Sunendar ${ }^{2}$, Sumiyadi $^{3}$ \\ Pascasarjana Program, Doktor Pendidikan Bahasa Indonesia, Universitas Pendidikan Indonesia ${ }^{1,2,3}$ \\ Email: cutnunun13@upi.edu ${ }^{1 *}$
}

\begin{abstract}
Abstrak
Culture shock atau sering kita sebut dengan istilah gegar budaya sangat berkaitan dengan keadaan dimana ada kekhawatiran dan ketidakmenentuan dari perasaan dan pikiran berlebih yang dialami orang-orang yang menempati wilayah baru dan asing. Di Unsika sendiri, kondisi culture shock sangat tampak jelas di kalangan mahasiswa khususnya. Kondisi tersebut bukan hanya dilatarbelakangi oleh status Unsika yang menjadi sebuah Perguruan Tinggi Negeri yang berada di daerah Karawang, juga karena posisi Kota Karawang yang terletak pada perbatasan Ibu Kota yang kita ketahui bersama merupakan pusat kehidupan Metropolitan. Sehingga, sedikit banyaknya mempengaruhi kondisi sosial masyarakat yang terbentuk dalam keadaan culture shock. Banyaknya mahasiswa pendatang dari berbagai daerah bahkan berasal dari luar pulau, menjadikan kondisi culture shock di lingkungan mahasiswa Unsika berada pada tingkat atau tahap culture shock yang beragam. Namun, dalam kajian ini ditemukan kunikan dimana rerata terbesar dari the crisis phase dialami oleh responden atau mahasiswa wanita. Sehingga sangat menarik untuk diteliti lebih lanjut lagi terhadap penyebab dan keterkaitannya.
\end{abstract}

Kata Kunci : Culture, Shock, Gegar, Budaya, Mahasiswa

\begin{abstract}
Culture shock is very much related to the situation where there are worries and uncertainties of excessive feelings and thoughts experienced by people who occupy new and unfamiliar territory. In Unsika Itself, the condition of culture shock is very apparent among students in particular. This condition is not only backgrounded by the status of Unsika which is a State University in the Karawang area, but also because of the position of the City of Karawang which is located on the border of the Capital City known as the center of Metropolitan life. Thus, it more or less affects the social circumstances of the community formed in a state of culture shock. The number of incoming students from various regions and even from the outside of the island, makes the condition of culture shock among the Unsika students varies. However, in this study it was found that the greatest average of the crisis phase was experienced by female students or respondents. Therefore, it is very interesting to be investigated further on the causes and their relevance.
\end{abstract}

Key Words : Culture, Shock, Concussion, Culture, Students

\section{PENDAHULUAN}

Culture Shock atau biasa disebut dengan Gegar budaya adalah salah satu tantangan yang tidak dapat dihindari oleh setiap individu ketika memasuki sebuah lingkungan baru. Dalam sebuah tentang Culture Shock: Adjustment to New Cultural Environments menyebutkan bahwa gegar budaya muncul karena adanya kecemasan sebagai dampak dari hilangnya semua tanda serta lambang yang sudah menjadi kebiasaan atau umum digunakan di kalangan masyarakat dalam hubungan keseharian [1]. Tanda-tanda tersebut mencakup seribu satu cara yang dilakukan dalam mengendalikan diri sendiri dalam menghadapi situasi seharihari.

Kehidupan sehari-hari, setiap manusia memiliki kebiasaan-kebiasaan yang menggambarkan interaksi manusia dengan lingkungan sosial kehidupannya. Kebiasaan tersebut terbentuk karena adanya pengaruh dari luar seperti. kebiasaan hidup, atau pembiasaan diri yang dibawa dari tempat asal, latar belakang budaya, keadaan geografis 
lingkungan tempat tinggal asal, tempat atau lingkungan baru, serta perkembangan zaman. Kebiasaan inilah yang dinamakan budaya.

Budaya berisi tatanan pengetahuan, pengalaman, kepercayaan, nilai, sikap, makna, hierarki, agama, waktu, peranan, hubungan ruang, konsep alam semesta, objek-objek materi dan milik yang diperoleh sekelompok besar orang dari generasi ke generasi melalui usaha individu dan kelompok [2]. Saat seseorang mengenal budaya baru atau budaya asing, mereka akan kehilangan 'petunjuk budaya' yang telah mereka miliki sebelumnya. Ibarat ikan yang keluar dari air, seseorang yang memasuki suatu budaya yang baru, mereka harus melakukan penyesuaian dengan lingkungan tempat tinggalnya. Proses penyesuaian inilah biasanya individu mengalami culture shock atau gegar budaya.

Culture shock kerap kali dianggap sebagai salah satu tantangan dalam konteks komunikasi antar budaya. Terlebih di era globalisasi seperti saat ini, dimana dunia seakan tanpa batas dan memungkinkan pertemuan antar satu budaya dengan budaya lainnya. Terlebih perkembangan zaman yang kian hari menyeret pada era globalisasi yang sudah barang tentu memiliki pengaruh besar terhadap lini bidang kehidupan, tak terkecuali pada bidang pendidikan. Globalisasi semakin membuka peluang bagi masyarakat untuk mendapatkan pendidikan yang lebih layak, salah satunya yaitu membuka peluang bagi masyarakat untuk berkuliah di universitas terbaik yang mereka inginkan, baik di sekitaran luar daerah maupun luar pulau bahkan luar negeri. Karena itulah, saat ini semakin banyak mahasiswa perantau yang datang ke suatu daerah untuk berkuliah. Seperti halnya mahasiswa di Universitas Singaperbangsa Karawang.
Semenjak Universitas Singaperbangsa Karawang berubah status menjadi PTN atau perguruan Tinggi Negeri, Kota Karawang menjadi semakin ramai oleh pendatang. Selain Kota karawang merupakan kota industri yang tidak sedikit karyawan dan karyawati di setiap perusahaan merupakan perantau atau masyarakat pendatang dari berbagai daerah di luar Karawang, Status yang disandang UNSIKA sebagai PTN juga sangat diminati oleh mahasiswa yang berasal dari luar Karawang. Sehingga, hal tersebut memunculkan keadaan culture shock di lingkungan sosial kehidupan di Karawang khususnya di kalangan mahasiswa Universitas Singaperbangsa Karawang.

Culture shock dapat terbentuk pada kalangan mana saja, termasuk diantaranya mahasiswa yang berkuliah di luar daerah tempat tinggalnya. Seperti dalam penelitian tentang "Culture Shock Communication Mahasiswa Perantauan di Madura", mengungkapkan bahwa culture shock merupakan fenomena yang wajar ketika orang bertamu atau mengunjungi budaya yang baru. Orang yang mengalami culture shock atau gegar budaya berada dalam kondisi belum terbiasa atau belum menemukan kenyamanan baik secara fisik maupun emosional. Adanya perbedaan latar belakang budaya, cara pandang, bahasa, lingkungan sosial, iklim dan cuaca, makanan, pakaian serta kebiasaan hidup menjadi serangkaian masalah yang harus dihadapi oleh mahasiswa perantau [3].

Dalam sebuah penelitian tentang "Foreign Students' Cultural Adjustment And Coping Strategies" menyebutkan bahwa mahasiswa perantau seperti halnya pendatang atau pelancong, mereka harus menghadapi perbedaan budaya serta harus melakukan penyesuaian diri [4]. Penyesuaian sebagai proses terus menerus yang merupakan tuntutan dari situasi satu ke situasi lainnya yang tidak bisa terjadi 
hanya dalam satu malam. Banyak hal yang dapat mempengaruhi proses penyesuaian diri, seperti variabel-variabel komunikasi dalam akulturasi, yakni faktor personal (intrapersonal), seperti karakteristik personal, motivasi individu, persepsi individu, pengetahuan individu dan pengalaman sebelumnya, selain itu juga dipengaruhi oleh keterampilan (kecakapan) komunikasi individu dalam komunikasi sosial (antarpersonal) serta suasana lingkungan komunikasi budaya baru tersebut [2]. Karena itulah, bukanlah hal yang baru jika mulai banyak peneliti yang mengangkat pengalaman gegar budaya mahasiswa sebagai tema penelitiannya menganai culture shock termasuk penelitian mengenai tingkat culture shock pada mahasiswa UNSIKA.

Kaitan dengan teori-teori culture shock atau gegar budaya, Oberg menyatakan gegar budaya merupakan reaksi individu saat berada dalam lingkungan baru yang belum dikenalnya. Reaksi awal yang muncul adalah kecemasan akibat individu kehilangan tanda-tanda yang dikenalnya dalam lingkungan lamanya [5]. Bocher juga mengungkapkan bahwa reaksi yang muncul berupa perasaan tidak nyaman berada di lingkungan yang tidak dikenal, dimana apabila individu terus mengembangkan perasaan ini dan tidak melakukan penyesuaian terhadap lingkungan yang baru dapat menyebabkan individu mengalami stress [5]. Hammersley dan Atikson mengungkapkan bahwa gegar budaya biasanya akan muncul pada hari-hari pertama individu datang ke lingkungan yang baru. Gegar budaya muncul karena ketika individu berada di lingkungan yang baru akan menemui kebiasaan-kebiasaan, adat maupun nilainilai yang berbeda dengan apa yang telah dianutnya di lingkungan yang lama, sehingga hal tersebut dapat menimbulkan trauma bagi dirinya [6].
Winkelmen menyatakan bahwa menyebabkan gegar budaya atau culture shock antara lain: a) Stress Reaction Stres menimbulkan reaksi fisiologis dalam jangkauan luas yang menyebabkan kerusakan fungsi sistem kekebalan tubuh dan meningkatkan kerentanan pada semua penyakit. Individu yang berada di lingkungan dan budaya yang baru mengalami pengalaman stres yang disebabkan oleh faktor fisiologis maupun psikologis. b) Cognitive Fatigue Budaya yang baru menuntut suatu usaha yang penuh kesadaran untuk memahami halhal yang diproses tanpa disadari dalam budaya seseorang. Usaha harus dilakukan untuk memahami arti dari bahasa baru dan komunikasi nonverbal, dalam lingkungan sosial yang baru. Usaha yang penuh kesadaran dan menuntut perhatian untuk memahami semua informasi baru ini sangat melelahkan dan menghasilkan kepenatan mental dan emosional. c)Role Shock Perubahan peran sosial dan relasi interpersonal memengaruhi kesejahteraan dan konsep diri, sehingga mengakibatkan individu mengalami syok peran. Dalam budaya yang baru, peran sebelumnya digantikan oleh peran yang belum dikenalnya. d) Personal Shock Harga diri, identitas diri, kesejahteraan, kepuasan hidup dijaga oleh sistem budaya individu [7].

Selain itu, ada empat tahapan timbulnya culture shock. yaitu:1) Tahapan pertama yaitu the honeymoon phase, suatu tahapan di mana kamu akan merasa bahagia setibanya di negara yang baru, apalagi yang belum pernah kamu kunjungi sebelumnya. 2) Tahap kedua, the crisis phase yaitu perbedaan di negara baru tidak pas baik itu makanannya, logat yang susah dimengerti, kebiasaan jual beli dan merasa kesepian. Hal tersebut hanya membuat kamu merasa terasing dari lingkungan. Namun kamu akan segera melaluinya jika mampu menyesuaikan diri dengan baik. 3) 
Tahap ketiga, the adjustment phase, dalam fase ini, kamu sudah mulai bisa berinteraksi dengan lingkungan di negara baru. 4) Tahap keempat bi-cultural phase, kamu merasa nyaman hidup dengan dua kebudayaan sekaligus. Ini merupakan indikasi bagus, karena kamu telah berhasil melalui suatu seleksi alam kecil. Namun ada pula mahasiswa yang terlalu memuja kebudayaan asing sehingga ketika pulang ke negeri sendiri, ia malah merasa asing kembali. Untuk itu harus ada keseimbangan antara memahami kebudayaan tanpa meninggalkan identitas kita sebagai bangsa Indonesia.

\section{METODE}

Penelitian ini menggunakan metode deskriptif dengan angket atau google form yang disebarkan guna mengukur tingkat culture shock yang dialami oleh mahasiswa UNSIKA dengan mengaitkan penyebab culture shock yang di alami oleh responden Mahasiswa UNSIKA) sesuai dengan teori Winkemen [7]. Objek yang dianalisis dalam penelitian ini adalah mahasiswa UNSIKA dari beberapa Fakultas dan Program Studi yang terjaring sebanyak 280 responden (mahasiswa UNSIKA). Peneliti melakukan pengumpulan data dengan menggunakan assessment (google form) atau pertanyaan pilihan faktual (hal-hal yang dialami dan dirasakan) dan skala tahap culture shock atau gegar budaya. Hasil dari google form dianalisis dan dikaitkan dengan penyebab culture shock yang dikemukakan oleh Winkelmen. Hasil analisisnya berupa penjelasan tentang tingkat culture shock yang dialami mahasiswa UNSIKA dengan penyebabnya. Setiap pilihan jawaban dengan tingkat ketidaknyamanan yang dirasakan, dikaitkan dengan penyebab culture shock tersebut.

\section{HASIL DAN PEMBAHASAN}

Layaknya seorang pendatang yang berkunjung ke tempat yang baru dengan budaya dan lingkungan yang sama sekali baru dan berbeda dengan lingkungan tempat tinggal asal, maka culture shock menjadi suatu tantangan yang tidak bisa dihindari oleh mahasiswa perantau. Tujuan awal mereka merantau adalah untuk berkuliah, dimana memiliki tugas untuk belajar dengan baik agar dapat memperoleh nilai yang membanggakan. Akan tetapi, apabila mahasiswa perantau ini mengalami sebuah kondisi seperti culture shock, keadaan tersebut dapat menjadi sebuah kendala di tempat mereka melanjutkan pendidikan, maka hal ini akan mengganggu kegiatan belajarnya. Hal ini sesuai dengan penelitian yang dilakukan oleh Pyvis dan Chapman tentang "Culture Shock and theinternational student 'offshore'”, menyebutkan bahwa culture shock atau gegar budaya pada mahasiswa yang belajar di luar daerah tempat tinggalnya menjadi suatu fenomena yang tak dapat dibiarkan [8]. Hal tersebut juga terjadi di UNSIKA (Universitas Singaperbangsa Karawang) dimana culture shock menimbulkan permasalahan akademik bagi mahasiswa. Hal ini juga kemungkinan besar akan berdampak pada institusi atau pihak kampus tempat mahasiswa pendatang belajar karena akan mempengaruhi kualitas pendidikan serta reputasi institusinya. Pentingnya penyesuaian diri bagi mahasiswa baru karena mempengaruhi mahasiswa tersebut untuk memaksimalkan potensinya [9]. Kegagalan penyesuaian diri pada mahasiswa akan berdampak merugikan mahasiswa baik ketika menjadi mahasiswa ataupun menghadapi dunia kerja nantinya. Penyesuaiam diri terhadap lingkungn kmpus harus terus dapat dapat diupayakan oleh mahasiswa baru ini sendiri. Hasil penelitian sebelumnya terlihat adanya keterkaitan antara culture shock dengan penyesuaian diri yaitu berkorelasi secara negatif [9]. Berikut hasil kajian lapangan yang dilakukan peneliti mengenai tingkat culture shock pada mahasiswa UNSIKA. 
Tabel 1. Tingkat Culture Shock

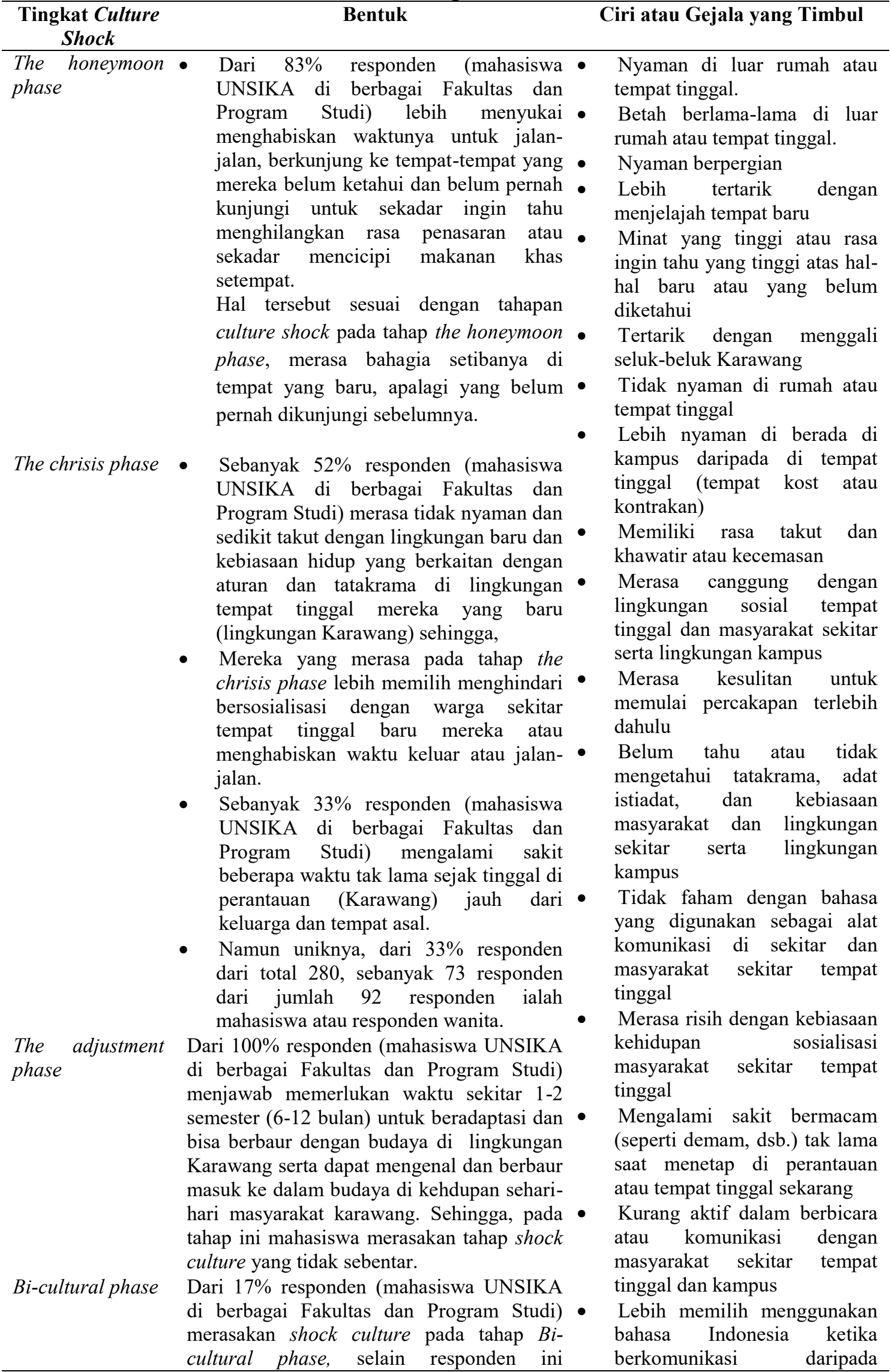


merupakan mahasiswa asal kota Karawang juga ada beberapa mahasiswa yang berasal dari luar Karawang namun memiliki kebiasaan hidup jauh dari keluarga atau lingkungan tempat tinggal asal (sebelum kuliah, mereka bersekolah di luar daerah tempat tinggal asalnya). Sehingga mereka merasakan cukup nyaman di tempat yang baru.
Jika dilihat dari ciri atau gejala yang timbul menunjukan penyebab culture shock sesuai dengan teori Winkelmen, yaitu Stress Reaction Stres yang menimbulkan reaksi fisiologis, Cognitive Fatigue karena adanya tantangan mengenal atau mempelajari hal atau bahasa baru, Role Shock berupa perubahan peran sosial dan relasi interpersonal, dan Personal Shock berupa gelaja yang timbul akibat bawaan dari diri pribadinya sendiri.

Culture shock atau dalam bahasa Indonesia disebut dengan gegar budaya adalah istilah psikologis yang menggambarkan keadaan dan perasaan seseorang dalam menghadapi kondisi lingkungan sosial dan budaya yang berbeda. Ada beberapa tahapan-tahapan Culture Shock yaitu, sebagai euforia awal, iritasi dan permusuhan, penyesuaian bertahap, penerimaan dan integrasi Selama ini pendidikan multikultural masih sebatas pada bahasan dan konsep yang selalu ingin dikembangkan dalam dunia pendidikan [10].

Culture shock tidak secara langsung mempengaruhi hasil belajar mahasiswa. Hal tersebut dikarenakan capaian pembelajaran di setiap program studi satu dengan yang lain berbeda [11], maka dari itu dapat dilihat bahwa memang tidak terdapat pengaruh langsung nya terhadap hasil belajar siswa terurama jika dibandingkan dengan program studi lain. dengan bahasa daerah asal masing-masing

\section{SIMPULAN}

Culture shock atau gegar budaya selalu dikaitkan dengan perpindahan tempat tinggal atau lingkungan baru. Namun, dalam kajian ini dapat disimpulkan bahwa rerata mahasiswa UNSIKA didominasi oleh pendatang atau bukan warga asli Karawang, sehingga culture shock sangat dialami oleh rerata mahasiswa UNSIKA sebagai responden. Culture shock yang dialami disebabkan oleh banyak faktor. Namun, dari faktor-faktor tersebut, ditemukan keunikan hasil data yaitu pada tahap culture shock, tahap crisis phase yang dialami didominasi oleh mahasiswa wanita. Sehingga sangat menarik untuk dilakukan kajian lebih lanjut terhadap pengaruh gender atau perbedaan antara wanita dan pria.

\section{DAFTAR PUSTAKA}

[1] K. Oberg, "Cultural Shock: Adjustment to New Cultural Environments," Pract. Anthropol., vol. 7, no. 4, pp. 177-182, 1960.

[2] M. D, Komunikasi Antar Budaya, Panduan Berkomunikasi dengan Orang-orang Berbeda Budaya. Bandung: Rosdakarya, 2010.

[3] N. Suryandari, "Culture Shock Communication Mahasiswa Perantauan Di Madura," $J$. Komunakasi Massa, vol. 1, no. 1, pp. 1-12, 2012.

[4] R. M. Sicat, "Foreign Students' Cultural Adjustment and Coping Strategies," in 2011 International Conference on Social Science and Humanity IPEDR vol.5 (2011) (C) (2011) IACSIT Press, Singapore, 
2011, pp. 338-241.

[5] nosensia D. IPramudiana and T. D. Setyorini, "Hubungan Antara Gegar Budaya dengan Penyesuaian Sosial Siswa Papua di Magelang," J. Paxis, vol. 1, no. 2, pp. 125-138, 2019.

[6] R. L. Atkinson, Pengantar Psikologi, Jilid 2. Tangerang: Interaksara, 2010.

[7] S. B. Goldstein and S. R. Keller, "U.S. College Students' Lay Theories of Culture Shock," Int. J. Intercult. Relat., vol. 47, no. 3, pp. 189-190, 2015.

[8] D. Pyvis and A. Chapman, "Culture Shock and The International Student 'Offshore",," J. Res. Int. Educ, vol. 4, no. 1, pp. 23-42, 2005.

[9] L. P. Sari dan D. Rusli, "Pengaruh Culture Shock Terhadap Penyesuaian Diri Mahasiswa Baru Yang Merantau," J. Ris. Psikol., vol. 4, no. 1, pp. 1-10, 2019.

[10] Darmawati, "Jurnal Sipatokkong BPSDM Sulawesi Selatan," J. Sipatokkong BPSDM Sulawesi Selatan, vol. 1, no. 2, pp. 137-142, 2020.

[11] Z. Mitasari dan Y. Istikomayanti, "Hubungan antara Culture Shock dengan Hasil Belajar Mahasiswa Tahun Pertama," J. Psikol. Pendidik. dan Konseling J. Kaji. Psikol. Pendidik. dan Bimbing. Konseling, vol. 4, no. 2, p. 105, 2019, doi: 10.26858/jpkk.v4i2.4316. 